Article

\title{
Nitrous Oxide Emissions and Methane Uptake from Organic and Conventionally Managed Arable Crop Rotations on Farms in Northwest Germany
}

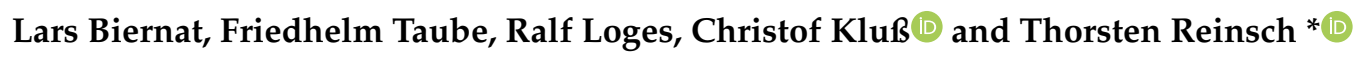 \\ Working Group Grass and Forage Science/Organic Agriculture, Institute for Crop Science and Plant Breeding, \\ Christian-Albrechts-University, 24118 Kiel, Germany; lbiernat@gfo.uni-kiel.de (L.B.); \\ ftaube@gfo.uni-kiel.de (F.T.); rloges@gfo.uni-kiel.de (R.L.); ckluss@gfo.uni-kiel.de (C.K.) \\ * Correspondence: treinsch@gfo.uni-kiel.de; Tel.: +49-431-880-1662
}

Received: 17 March 2020; Accepted: 15 April 2020; Published: 17 April 2020

check for updates

\begin{abstract}
Land-use extensification by shifting from conventional to organic arable farming is often discussed as a measure for reducing greenhouse gas (GHG) emissions from agricultural land. Doubts about the benefits arise when emissions are calculated per product unit, particularly where high yields are possible under conventional management. Among the non- $\mathrm{CO}_{2}$ GHG emissions, nitrous oxide $\left(\mathrm{N}_{2} \mathrm{O}\right)$ is the main contributor from arable land and is controlled by soil type, environmental conditions and management. In order to investigate how land-use change from conventional to organic farming would perform under highly productive site conditions in northwest Germany, and how this would affect the important greenhouse gases $\mathrm{N}_{2} \mathrm{O}$ and methane $\left(\mathrm{CH}_{4}\right)$, an on-farm field research was conducted over two experimental years. Two site-specific organic crop rotations, (i) with $25 \%$ legumes (grass + clover-winter wheat-winter rye-oats) and (ii) with $40 \%$ legumes (grass + clover-winter wheat-winter rye-spring field peas-winter rye), were compared with (iii) a conventional arable rotation (winter oilseed rape-winter wheat-winter wheat-sugar beet-winter wheat) and two reference systems, (iv) extensive grassland and (v) a beech forest), which were chosen as the baseline. The results showed that organic farming had lower $\mathrm{N}_{2} \mathrm{O}$ emissions of $0.7 \mathrm{~N}_{2} \mathrm{O}-\mathrm{N} \mathrm{ha}^{-1}$ year $^{-1}$ than the conventional rotation, with $2.1 \mathrm{~kg} \mathrm{~N}_{2} \mathrm{O}-\mathrm{N} \mathrm{ha}^{-1}$ year $^{-1}$ $(\mathrm{p}<0.05)$, but higher emissions than the extensive grassland $\left(0.3 \mathrm{~kg} \mathrm{~N}_{2} \mathrm{O} \mathrm{ha}^{-1}\right.$ year $\left.^{-1}\right)$ and beech forest $\left(0.4 \mathrm{~kg} \mathrm{~N}_{2} \mathrm{O} \mathrm{ha}^{-1}\right.$ year ${ }^{-1}$ ). $\mathrm{CH}_{4}$ emissions were a negligible part of total GHG emissions (as $\mathrm{CO}_{2}$ equivalents) in the two arable systems, and considerable uptake of $\mathrm{CH}_{4}$ from the forest soils showed this was a GHG sink in the first experimental year. Organic systems produced up to $40 \%$ lower crop yields, but the emissions per product unit in rotation (iii) was not superior to (ii) during the two experimental years. Thus, arable organic farming showed the ability to produce agricultural commodities with low $\mathrm{N}_{2} \mathrm{O}$ emissions per unit area, and no differences in product-related emissions compared with conventional farming. Conventional and organic systems both showed potential for further mitigation of $\mathrm{N}_{2} \mathrm{O}$ emissions by controlling the field level nitrogen surplus to a minimum, and by the optimized timing of the removal of the grass-clover ley phase.
\end{abstract}

Keywords: eco-efficiency; greenhouse gas (GHG) emissions; on-farm research; system comparison; crop yield

\section{Introduction}

Nitrous oxide $\left(\mathrm{N}_{2} \mathrm{O}\right)$ is an important greenhouse gas (GHG) in agriculture and has a global warming potential (GWP) 265 times that of carbon dioxide $\left(\mathrm{CO}_{2}\right)$ over a 100-year time horizon [1]. Agricultural $\mathrm{N}_{2} \mathrm{O}$ emissions are therefore considered to contribute significantly to climate change [2] 
and, additionally, are involved in the degradation of the protective ozone layer [3,4]. At a global scale, about $62 \%$ of atmospheric $\mathrm{N}_{2} \mathrm{O}$ emissions are attributed to soils [5], which is the equivalent of $13 \mathrm{Mt}$ $\mathrm{N}_{2} \mathrm{O}-\mathrm{N}$ annually [6]. Soil-derived $\mathrm{N}_{2} \mathrm{O}$ emissions occur mainly as an intermediate stage during the denitrification and nitrification processes [7-11]. Its production is controlled by available nitrogen $(\mathrm{N})$ in the soil and different abiotic factors that stimulate or inhibit biological activity [12]. These factors comprise the availability of easily degradable organic matter $[13,14]$, temperature, $\mathrm{pH}[15,16]$ and soil moisture [14,17]. The magnitude of $\mathrm{N}_{2} \mathrm{O}$ emissions is often characterized by high spatial and temporal variation [12,18], and in agricultural systems increased use of $\mathrm{N}$ fertilization is associated with increased $\mathrm{N}_{2} \mathrm{O}$ emissions [19-22]. Thus, in mitigating the causes of global warming associated with agriculture and land use, adopting management changes that can help to reduce $\mathrm{N}_{2} \mathrm{O}$ emissions are increasingly important [23].

Agricultural systems can also act as a considerable GHG sink. In addition to carbon sequestration in soils and plants, additional soil GHG consumption can take place by methane $\left(\mathrm{CH}_{4}\right)$-oxidizing bacteria that use $\mathrm{CH}_{4}$ (GWP of 28) as an energy source. However, in relation to the most important direct non- $\mathrm{CO}_{2}$ GHG emissions $\left(\mathrm{N}_{2} \mathrm{O}\right.$ and $\left.\mathrm{CH}_{4}\right)$, the sink strength of soils is comparatively low when expressed in $\mathrm{CO}_{2}$ equivalents on an area basis [24,25], but its value has to be considered in GHG inventories.

In Germany, agriculture contributes $80 \%$ to the total $\mathrm{N}_{2} \mathrm{O}$ emissions [26]. One measure proposed by the government for reducing agricultural GHG emissions is to increase the share of organic farming to $20 \%$ of the total utilized agricultural area [27]. On the area basis, it appears likely that emissions will be reduced by this measure, as conventional farming systems are usually characterized by high inputs of mineral $\mathrm{N}$ fertilizers and, therefore, are often associated with high $\mathrm{N}$ losses to the environment [28]. Conversely, on farms managed by organic farming methods, there is a dependency on internal $\mathrm{N}$-supply from biological nitrogen fixation (BNF), which can lead to reduced $\mathrm{N}_{2} \mathrm{O}$ emissions because external $\mathrm{N}$ inputs are lower [29]. However, this situation may also have the unintended consequence of stimulating considerable $\mathrm{N}_{2} \mathrm{O}$ releases from agricultural soils. This can arise due to the high quantities of easy decomposable organic matter coincident with narrow $\mathrm{C} / \mathrm{N}$ ratios of plant material, creating favorable conditions for $\mathrm{N}_{2} \mathrm{O}$ release in soils. Several authors have found increased $\mathrm{N}_{2} \mathrm{O}$ emissions after ploughing grass-clover swards [30,31]. Consequently, some authors have concluded that organically managed fields can lead to higher $\mathrm{N}_{2} \mathrm{O}$ emissions compared with conventional systems [32]. The prevailing farm management practices could also have diverse effects on $\mathrm{N}_{2} \mathrm{O}$ emissions, depending on the types and timing of manure and other types of fertilizer application [33], and the composition and quality of incorporated crop residues [34].

A further important consideration is that, in organic arable farming, crop yields per hectare are often much lower than in conventional systems [35,36]. This is highly relevant because the climate impact of agricultural production is often not only evaluated as emissions per unit of area, but as emissions per product unit [37]. Recent studies have recommended that $\mathrm{N}_{2} \mathrm{O}$ emissions from agricultural production should be expressed as a function of dry matter yield, e.g., grain equivalents in arable farming systems [38]. Against this background, it is important to question whether an increased share of farmland used for organic farming would result in reduced emissions per product unit. However, comparative datasets about the environmental impacts of the systems are lacking. Beyond this, there are further questions about the extent of arable agricultural production's contributions to national GHG inventories, in comparison with extensive grassland or reserve systems. For the latter, it is not only the question of the amount of GHG emissions produced, but also the question of the productivity needed to maintain the economic resilience of farmers and ensure food security. In the forestry sector in particular, there are current considerations on how to increase the sector's land-use share as a possible climate change mitigation strategy. However, it can take several years before forests can provide a timber harvest and thereby support livelihoods.

The ongoing public discussion about the efficiency and resilience of future production systems has focused attention on the need for studies beyond academic approaches for measuring $\mathrm{N}_{2} \mathrm{O}$ emissions 
from arable conventional and organic systems, under common and current agricultural management, to examine whether GHG mitigation targets are fulfilled. In this context, a more detailed understanding of $\mathrm{N}$ losses is also crucial for further lifecycle impact assessments, as inaccurate prediction of $\mathrm{N}$ cycles when comparing organic and conventional production can result in large errors, which often show disadvantages for organic systems [36]. Moreover, typical regional production systems have to be chosen, rather than simple comparisons of identical crop rotations. Organic farming has different requirements for crops, such as greater reliance on $\mathrm{N}$-fixing legumes compared with conventional systems that use external synthetic $\mathrm{N}$, leading to different agricultural commodities and environmental impacts [39].

Accordingly, in this paper, we present results from an on-farm study to address these important questions: (1) Can stockless arable organic farming reduce direct $\mathrm{GHG}\left(\mathrm{N}_{2} \mathrm{O}\right.$ and $\left.\mathrm{CH}_{4}\right)$ emissions from soils per ha and per product unit relative to a conventional stockless arable system, on highly productive sites in northern Germany? (2) What are the main drivers for the important field-level $\mathrm{N}_{2} \mathrm{O}$ emissions in the investigated systems, and how they can be improved? (3) To what extent do the examined arable systems behave in terms of GHG emissions compared with other referenced land-use systems (extensive grassland and beech forest)?

\section{Materials and Methods}

\subsection{Research Area}

The region where the study was conducted in Schleswig-Holstein, northern Germany, has a hilly terminal-moraine landscape and supports approximately 400,000 ha of agricultural land that is mainly used for intensive arable cropping. The weather is characterized by a temperate oceanic climate. Mean (1981-2010) annual temperature is $8.9^{\circ} \mathrm{C}$ and annual precipitation is $737 \mathrm{~mm}$. The region, together with similar areas along the Baltic Sea coast of Denmark, southern Sweden and north-east Germany, is one of the most suitable regions in Europe for cereals, oilseed rape and winter wheat; e.g., yields for winter wheat on commercial farms typically exceed $9.0 \mathrm{tha}^{-1}$ (based on 6-year average 2008-2013). Organic farming is currently practiced on only $3.7 \%$ of the utilized agricultural area in this region. In view of current policy aims to increase land under organic management, we considered on-farm investigations under these favorable climate and soil conditions to be appropriate to answering the question of to what extent a shift from conventional to organic arable farming would affect productivity and GHG emissions from sandy loam soils used for arable cropping.

\subsection{On-Farm Research Design}

The two-year field study (1st year: October 2012-September 2013; 2nd year: October 2013-September 2014) was conducted on 400 ha land comprised of arable land, beech forest and permanent grassland $\left(53^{\circ} 39^{\prime} \mathrm{N}, 10^{\circ} 34^{\prime} \mathrm{E}\right)$. All land-use types were arranged completely randomized within this area. The arable land was managed under the common agricultural practice for that area. The study area included two organically managed arable crop rotations and a typical conventional stockless cropping system with a history of more than ten years of continuous management. The crop rotations were established randomly on fields of 5-23 ha, and every crop in each crop rotation was present during both experimental years. There were four replicates for investigations established in each field to provide a representative average for each field. Soils were classified as sandy loam (10.6-11.4\% clay, $26.3-29.4 \%$ silt and $59.4-63.0 \%$ sand in the $0-30 \mathrm{~cm}$ topsoil), with dominant soil types being Luvisols, Cambisols and Haplic Stagnosols.

Total precipitation during the experimental years (1st year: $645 \mathrm{~mm}$; 2nd year: $615 \mathrm{~mm}$ ) was less than the long-term average $(737 \mathrm{~mm})$. Compared with the long-term average of $8.9^{\circ} \mathrm{C}$, air temperature during the study period was similar in the first experimental year $\left(8.4^{\circ} \mathrm{C}\right)$ but higher in the second year $\left(10.4{ }^{\circ} \mathrm{C}\right)$. The differences between the two experimental years are also shown by numbers of days with temperatures below freezing point. In the first winter period, there were 62 days with daily 
average temperatures below $0{ }^{\circ} \mathrm{C}$, whereas only 16 days with sub-zero temperatures were recorded in the second year (Figure 1).

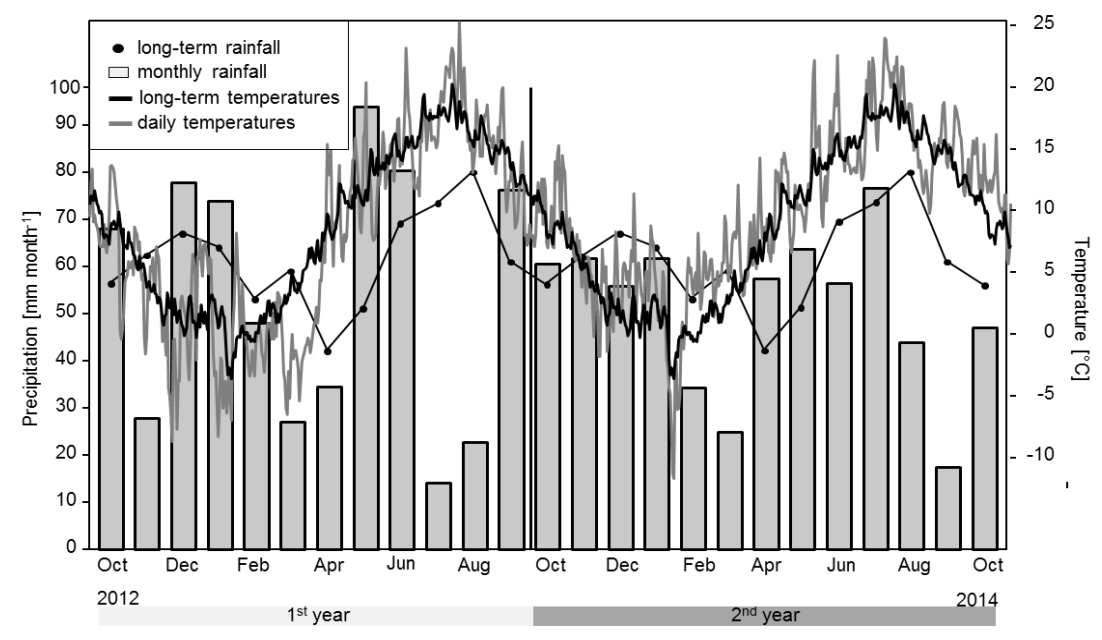

Figure 1. Monthly sum of precipitation in $\mathrm{mm} \mathrm{month}^{-1}$ (grey bars) compared with the long-term averages (black dots), and daily mean air temperature (grey line) compared with the long-term average (black line) during the experimental years (October 2012-October 2014).

\subsection{Crop Rotations, N Inputs and Crop Management}

The $\mathrm{N}$ intensity of the two tested organic systems was controlled by the proportion of legumes in the crop rotations. We distinguished between "organic-low-BNF" as a four-crop rotation (i. grass-clover (Trifolium pratense, / Lolium multiflorum), ii. winter-wheat (Triticum aestioum, cv. 'Naturastar'), iii. winter-rye (Secale cereale, cv. 'Dukato'), iv. oats (Avena sativa, cv. 'Ivory')) with a share of 25\% legumes; and "organic-semi-BNF" as five-crop rotation (i. grass-clover (T. pratense/L. multiflorum), ii. winter-wheat (T. aestivum, cv. 'Naturastar'), iii. winter-rye (S. cereale, cv. 'Dukato'), iv. peas (Pisum sativum, cv. 'Santana'), v. winter-rye (S. cereale, cv. 'Dukato')) with a share of $40 \%$ legumes. The conventional system comprised an intensive five-crop rotation (i. winter oilseed rape (Brassica napus, cv. 'Visby')), ii. winter-wheat (T. aestivum, cv. 'Tobak'), iii. winter-wheat (T. aestivum cv. 'JB Asano'), iv. sugar beets (Beta vulgaris, cv. 'Sabrina'), v. winter-wheat (T. aestivum, cv. 'Touareg')).

In order to account for the $\mathrm{N}$ inputs in the organic systems, the determination of BNF by forage legumes was based on the empirical model of Høgh-Jensen et al. [40]. This approach is calculated from measures of dry matter (DM) yield of legumes and their N\%. The relevant default parameters were set according to the assumptions of a 1-2-year-old grass-red clover sward given by Høgh-Jensen et al. [40]. To determinate the amount of $\mathrm{N}_{2}$ fixation of grain legumes, we used the extended difference method (reference crop oat) according to Wichmann et al. [41]. Based on these models the calculated average BNF for the crop rotation elements was 50 and $65 \mathrm{~kg} \mathrm{~N}^{-1}$ year $^{-1}$ for organic-low-BNF and organic-semi-BNF, respectively, with no further $\mathrm{N}$ amendments. In the conventional system, however, $\mathrm{N}$ inputs were primarily as mineral fertilizers with small amendments of digestates and pig slurry, with total $\mathrm{N}$ rates of $224 \mathrm{~kg} \mathrm{~N}^{-1}$ year $^{-1}$. The $\mathrm{N}$ rates were consistent with the agricultural practice recommended for each specific crop (Table 1 ).

Soil cultivation was adapted to the specific weed infestations and therefore varied between systems, years and crops. In the organic systems the primary soil tillage was carried out by ploughing, whereas a cultivator was used in the conventional system. In the organic systems the arable land for summer crops was managed mechanically in autumn and was not sown or covered with any plant residues during winter, with bare ground until seeding in spring (see Supplementary Information Table S1). Grass-clover mixtures in the first year were established by under-sowing in spring. The grass-clover mixtures in the second year were sown in August, shortly after harvesting. Grass-clover swards were cut three times a year in organic-low-BNF and twice a year in organic-semi-BNF. 
Table 1. Application dates and amounts of $\mathrm{N}$ fertilizer, manure and digestate on different crops within the conventional arable system.

\begin{tabular}{|c|c|c|c|c|c|c|c|}
\hline \multirow{2}{*}{$\begin{array}{c}\text { Rotation Element } \\
\text { Treatment } \\
\end{array}$} & \multirow[t]{2}{*}{ Year } & \multicolumn{5}{|c|}{ Amount [kg N ha ${ }^{-1}$, Fertilizer Type and Date of $\mathbf{N}$ Application } & \multirow[t]{2}{*}{ Total Input [kg N ha-1] } \\
\hline & & 1. & 2. & 3. & 4. & 5. & \\
\hline \multirow{2}{*}{ Oilseed rape } & 1 st & $31^{\mathrm{b}}(09-$ Sep-12) & $138^{\mathrm{c}}(28-\mathrm{Feb}-13)$ & $42^{\mathrm{d}}$ (08-Apr-13) & & & 211 \\
\hline & 2nd & $106^{\mathrm{f}}(30-$ Aug-13) & $130^{\mathrm{c}}(18-\mathrm{Feb}-14)$ & $74^{\mathrm{f}}(26-\mathrm{Feb}-14)$ & $31^{\mathrm{d}}(01-$ Mar-14) & & 341 \\
\hline \multirow{2}{*}{ Winter wheat } & 1st & $83^{\mathrm{c}}(06-\mathrm{Mar}-13)$ & $25^{\mathrm{d}}(08-\mathrm{Apr}-13)$ & $38^{\mathrm{b}}$ (22-Apr-13) & $32^{\mathrm{d}}$ (21-May-13) & & 178 \\
\hline & 2nd & $80^{c}(25-\mathrm{Feb}-14)$ & $31^{\mathrm{d}}(08-M a r-14)$ & $55^{\mathrm{c}}(06-\mathrm{Apr}-14)$ & $52^{\text {c }(18-M a y-14)}$ & & 218 \\
\hline \multirow{2}{*}{ Winter wheat } & 1st & $88^{\text {c }}$ (06-Mar-13) & $61^{\text {e }}$ (06-Mar-13) & $29^{\mathrm{d}}$ (12-Apr-13) & $52^{c}$ (17-Apr-13) & $37^{\text {c }}$ (21-May-13) & 267 \\
\hline & 2nd & $95^{\mathrm{c}}(25-\mathrm{Feb}-14)$ & $82^{\text {e }}$ (13-Mar-14) & $32^{\mathrm{d}}$ (10-Mar-14) & $21^{\mathrm{b}}$ (07-Apr-14) & $55^{c}$ (17-May-14) & 285 \\
\hline Sugar beet & 2nd & $36^{\mathrm{b}}$ (11-Mar-14) & $100^{\mathrm{c}}(23-\mathrm{Apr}-14)$ & & & & 136 \\
\hline \multirow{2}{*}{ Winter wheat } & 1 st & $101^{\mathrm{c}}$ (06-Mar-13) & $25^{\mathrm{d}}$ (08-Apr-13) & $36^{\mathrm{b}}$ (22-Apr-13) & $60^{\mathrm{c}}$ (21-May-13) & & 222 \\
\hline & 2nd & $92^{c}(25-F e b-14)$ & $31^{\mathrm{d}}(08-M a r-14)$ & $55^{\mathrm{c}}$ (03-Apr-14) & $55^{\text {c }}$ (18-May-14) & & 233 \\
\hline
\end{tabular}

a: CAN, Calcium ammonium nitrate; ${ }^{b}$ : DAP, Diammonium Phosphate; ${ }^{c}$ : Urea; ${ }^{d}$ SSA ammonium sulphate; ${ }^{\mathrm{e}}$ : pig slurry; ${ }^{\mathrm{f}}$ : biogas digestate; the total N amount is shown for organic fertilizers. 
In addition, the study included two permanent land use types as reference systems. These were permanent extensive grassland and beech forest, each of which occupied more than 5 ha. The permanent grassland has been cut twice each year since its establishment in 2004. The sward composition showed typical patterns for extensively used permanent grassland, with $49 \%$ L. perenne, $13 \%$ T. repens, $12 \%$ P. trivialis, $8 \%$ T. sect. Ruderalia, $6 \%$ D. glomerata, $5 \%$ P. pratensis and $7 \%$ other species. The beech forest has existed in its current form for more than 50 years. Only beech trees were present in the study area. Both treatments were included in the research area to provide additional information for either extensively managed agricultural land (grassland) or reserve area (beech forest) as a baseline scenario for comparison with land-use for arable agriculture. Both reference systems were on land with the same soil conditions as described above.

\subsection{Flux-Measurements}

Fluxes of $\mathrm{N}_{2} \mathrm{O}$ and $\mathrm{CH}_{4}$ were measured with the static closed chamber method [42]. The minimum sampling frequency was once a week in all rotations and crop, taken between 10:00 a.m. and 12:00 p.m. during the two experimental years (01 October 2012-14 October 2014). In a pre-treatment, four collars $(\mathrm{d}=60 \mathrm{~cm}, \mathrm{~h}=15 \mathrm{~cm})$ per crop $(\mathrm{n}=4)$ made from polyvinyl chloride $(\mathrm{PVC})$ were installed in the $10 \mathrm{~cm}$ soil depth at an angle of $45^{\circ}$ with uniform distances in order to capture a representative area across each field. The collars were removed briefly during harvesting and tillage operations. During the flux measurements, the collars were closed gas tight with white PVC chambers $(\mathrm{d}=60 \mathrm{~cm}$, $\mathrm{h}=35 \mathrm{~cm}$ ). The area between the basal ring and chamber was tightened with a taut butyl rubber band. The chambers were closed for $60 \mathrm{~min}$ on each measurement day, when a fan within each chamber allowed homogenized air conditions before sampling. Gas samples were taken at 0, 20, 40 and $60 \mathrm{~min}$ after closure through a gas-tight septum on the top of the chamber using a $30 \mathrm{ml}$ syringe. Samples were directly transferred into $12 \mathrm{ml}$ pre-evacuated septum-capped vials (Labco, High Wycombe, UK). After fertilizer application events, measurements were conducted more frequently over two weeks at irregular intervals. The size of the collars and chambers allowed for undisturbed plant growth within the collars. In the later growth stages, when plant growth exceeded chamber height, extensions $(\mathrm{h}: 35 \mathrm{~cm})$ were used. Gas samples were analyzed for $\mathrm{N}_{2} \mathrm{O}$ and $\mathrm{CH}_{4}$ through a gas chromatograph (SCION 456-GC, Bruker, Leiderdorp, Netherlands). Samples were injected using an autosampler (model $271 \mathrm{LH}$, Gilson Inc., Middleton, WI, USA). Data were processed using the software Compass CDS (Version 3.0.1). The change of gas concentration in the chamber headspace during the measurement was calculated by linear regression. In order to calculate the $\mathrm{CO}_{2}$-equivalents $\left(\mathrm{CO}_{2 \mathrm{eq}}\right)$, the GWP values of 265 for $\mathrm{N}_{2} \mathrm{O}$ and 28 for $\mathrm{CH}_{4}$ were used [1]. In order to calculate the product carbon footprint (PCF), derived from the two non- $\mathrm{CO}_{2}$ trace gases, namely $\mathrm{N}_{2} \mathrm{O}$ and $\mathrm{CH}_{4}$, the accumulated annual $\mathrm{CO}_{2}$ eq fluxes were divided by the functional unit grain equivalents (see Section 2.5.) and is referred to as $\mathrm{PCF}_{\mathrm{NON}-\mathrm{CO} 2}$ in the remainder of the paper.

\subsection{Determination of Yield and N-Balance}

The fresh-matter (FM) yields of crops were recorded at a field scale by weighing the commercial machinery with the harvested crops. To calculate the dry matter yields, additional subsamples of aboveground biomass were taken with shears at random in the field, with five replicates prior to each harvest. In the permanent grassland and grass-clover swards, subsamples were taken at a stubble height of $5 \mathrm{~cm}$ from an area of $0.25 \mathrm{~m}^{2}$. In crops, the biomass samples were taken on $1.0 \mathrm{~m}^{2}$ directly above the soil surface, although for sugar beet, samples were subdivided into primary and secondary products from yield samples. The dry matter contents of the subsamples were estimated after oven drying for $24 \mathrm{~h}$ at $58^{\circ} \mathrm{C}$. After drying, the samples were milled to pass a $2 \mathrm{~mm}$ sieve (Cyclotec mill, Foss, Hillerød, Denmark). Subsequently, the $\mathrm{N}$ and $\mathrm{C}$ contents of all samples were measured using a $\mathrm{C} / \mathrm{N}$ analyzer (Vario Max CN, Elementar, Hanau, Germany). The values for the $\mathrm{N}$ balance $\left(\mathrm{kg} \mathrm{N} \mathrm{ha}^{-1} \mathrm{year}^{-1}\right.$ ) 
were calculated after deduction of the $\mathrm{N}$ yields ( $\mathrm{N}$ output) from the amounts of applied $\mathrm{N}$ and $\mathrm{BNF}$ (N-input):

$$
\mathrm{N} \text { balance }\left[\mathrm{kg} \mathrm{N} \mathrm{ha}^{-1} \text { year }^{-1}\right]=\mathrm{N} \text { input }-\mathrm{N} \text { output }
$$

For product unit comparisons, the functional unit "grain equivalents" (GE) was chosen, using values obtained from the German Federal Ministry of Food and Agriculture [43], with GE $=1.04$ for wheat, $\mathrm{GE}=1.01$ for rye, $\mathrm{GE}=0.84$ for oats, $\mathrm{GE}=1.04$ for peas, $\mathrm{GE}=1.3$ for oilseed rape, $\mathrm{GE}=0.23$ for sugar beets and GE $=0.58$ for grass-clover. One GE was defined as the feeding value of $100 \mathrm{~kg}$ barley. The GE factors were multiplied by the DM yields of the different crops.

\subsection{Statistical Analysis}

The statistical software R (2015) was used to evaluate the data. The data evaluation started with the definition of an appropriate statistical model. The data were normally distributed and heteroscedastic due to the experimental year and single crop rotation elements within the system. For comparison of crops within a single system the statistical model included the experimental year (first and second) and crops, as well as their interaction terms as fixed factors. For management system comparison, the experimental year and crops were considered as random factors. Based on these mixed effect models an analysis of variance (ANOVA) was conducted to answer the questions of the trial. Multiple contrast tests were then conducted in order to compare the several levels of the influence factors. In addition, simple linear regression models were developed to test whether $\mathrm{N}_{2} \mathrm{O}$ emissions can be estimated from other measured variables (e.g., $\mathrm{N}$ balance, $\mathrm{CN}$ ratio of crop residues). The significance of the tested factors, comparisons of means, and regression equations (intercepts and slopes) were declared when $\mathrm{p}<0.05$.

\section{Results}

\subsection{GHG-Fluxes}

The experimental year showed an interaction with crop and the tested systems on GHG fluxes per ha ${ }^{-1}$ and $\mathrm{PCF}_{\mathrm{NON}-\mathrm{CO} 2}$ (Table 2).

Table 2. Level of significance for the impact of period, crop within a system, as well as the impact of the interaction of both factors on $\mathrm{N}_{2} \mathrm{O}, \mathrm{CH}_{4}, \mathrm{CO}_{2 \mathrm{eq}} \mathrm{ha}^{-1}$ and product carbon footprints (PCFNON-CO $)$.

\begin{tabular}{ccccc}
\hline Effect & $\mathbf{N}_{\mathbf{2}} \mathbf{O}$ & $\mathbf{C H}_{\mathbf{4}}$ & $\mathbf{C O}_{\mathbf{2} \text { eq }} \mathbf{h a}^{-\mathbf{1}}$ & $\mathbf{P C F}_{\text {NON-CO2 }}$ \\
\hline Period & $\mathrm{ns}$ & $\mathrm{p}<0.001$ & $\mathrm{~ns}$ & $\mathrm{~ns}$ \\
\hline Crop & $\mathrm{p}<0.001$ & $\mathrm{p}<0.001$ & $\mathrm{p}<0.001$ & $\mathrm{p}<0.001$ \\
\hline Period $^{*}$ Crop & $\mathrm{p}<0.001$ & $\mathrm{p}<0.001$ & $\mathrm{p}<0.001$ & $\mathrm{p}<0.001$ \\
\hline
\end{tabular}

Daily GHG fluxes measured during the two experimental years in the arable crop rotations and reference system are presented in Figures 2-4. Measured $\mathrm{N}_{2} \mathrm{O}$ fluxes in all systems ranged from 0.0 to $0.13 \mathrm{~kg} \mathrm{~N}_{2} \mathrm{O}-\mathrm{N} \mathrm{ha}{ }^{-1}$ day $^{-1}$. The fluxes showed a high variability during the year and among the systems. The lowest $\mathrm{N}_{2} \mathrm{O}$ fluxes during the two years were recorded in the beech forest and in the extensively managed grassland (see Supplementary Figure S1). In the comparison of the tested arable crops, grass-clover showed the lowest $\mathrm{N}_{2} \mathrm{O}$ fluxes (Figures 2 and 3). In general, there were clearly detectable emission peaks for conventional crops when fertilizer dressings took place (Figure 4). In all systems, there were additional $\mathrm{N}_{2} \mathrm{O}$ peaks after soil-tillage and frost-thaw events during winter. The organically managed crops showed low emissions on average, with the highest figures for cereals, of $1 \mathrm{~kg} \mathrm{~N}_{2} \mathrm{O}-\mathrm{N} \mathrm{ha}^{-1}$ year ${ }^{-1}$ or less. In comparison, the conventional system had the highest emissions, with annual emissions of $>1.5 \mathrm{~kg} \mathrm{~N}_{2} \mathrm{O}-\mathrm{N} \mathrm{ha}^{-1}$ (Table 3). Annual $\mathrm{N}_{2} \mathrm{O}$-emissions in the two reference systems (grassland and beech forest) were lowest on average and were below $0.5 \mathrm{~kg} \mathrm{~N}_{2} \mathrm{O}-\mathrm{N} \mathrm{ha}^{-1}$ year $^{-1}$ in both experimental years. 


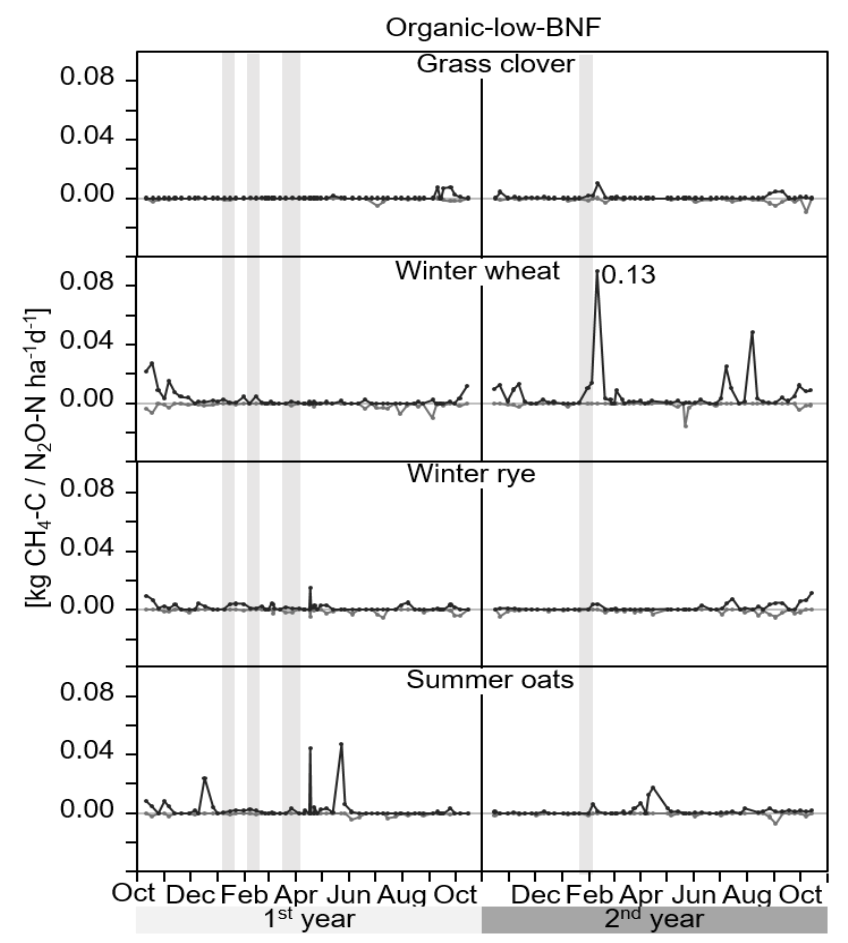

Figure 2. Daily $\mathrm{N}_{2} \mathrm{O}$ - (black line and dots) and $\mathrm{CH}_{4}$-fluxes (grey line and dots) for each crop within the crop rotation of the organic-low-BNF during the study period (October 2012-October 2014). The grey background represents periods with mean daily temperatures below $0{ }^{\circ} \mathrm{C}$. Mean values are shown $(\mathrm{n}=4)$.

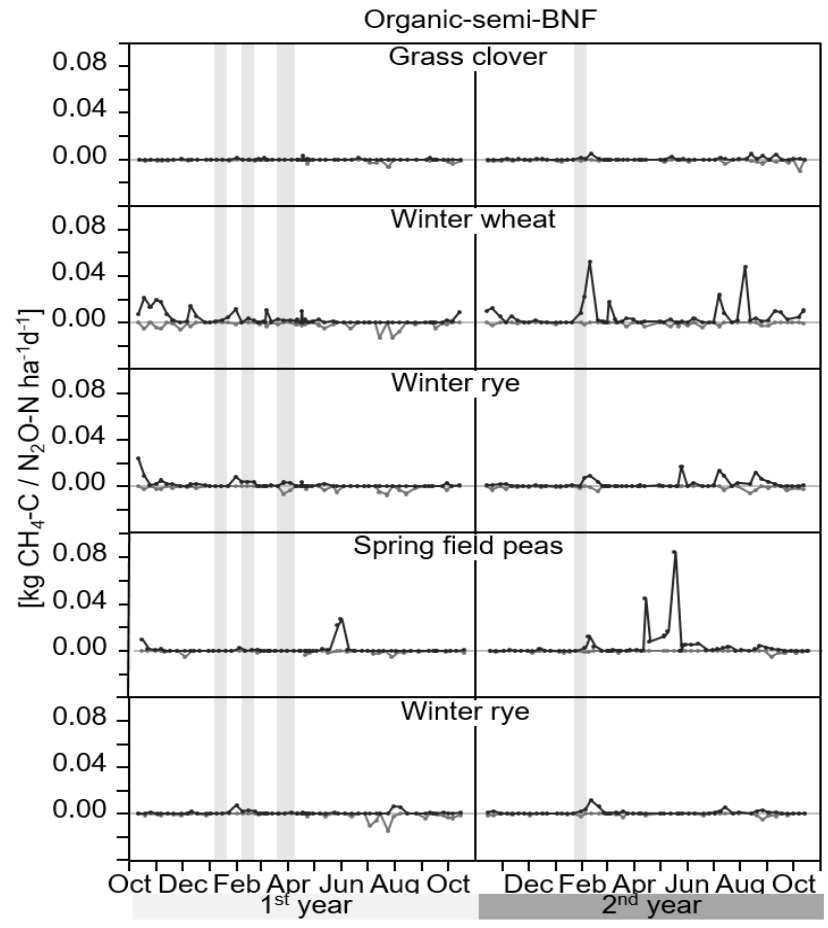

Figure 3. Daily $\mathrm{N}_{2} \mathrm{O}$ - (black line and dots) and $\mathrm{CH}_{4}$-fluxes (grey line and dots) for each crop within the crop rotation of the organic system organic-semi-BNF during the study period (October 2012-October 2014). The grey background represents periods with mean daily temperatures below $0{ }^{\circ} \mathrm{C}$. Mean values are shown $(\mathrm{n}=4)$. 


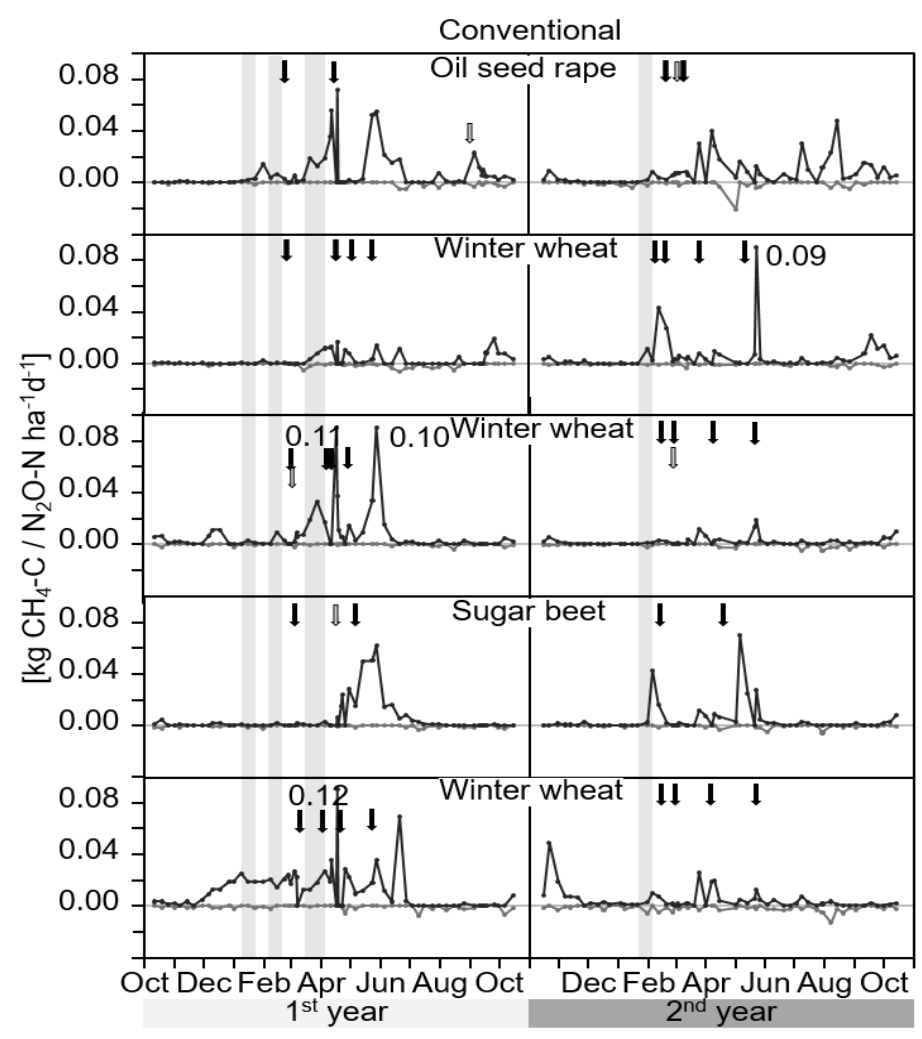

Figure 4. Daily $\mathrm{N}_{2} \mathrm{O}$ - (black line and dots) and $\mathrm{CH}_{4}$-fluxes (grey line and dots) for each crop within the crop rotation of the conventional system during the study period (October 2012-October 2014). The black arrows indicate applications of mineral $\mathrm{N}$ fertilizer. The grey arrows indicate applications of organic manure. The grey background represents periods with mean daily temperatures below $0{ }^{\circ} \mathrm{C}$. Mean values are shown $(n=4)$. 
Table 3. Accumulated $\mathrm{N}_{2} \mathrm{O}, \mathrm{CH}_{4}$ and global warming potential (GWP) per ha within one crop rotation (system). Yields were estimated at farm level by weighing the harvested crops. Product carbon footprints (PCFNON-CO ${ }_{2}$ ) were derived from GWP and grain equivalents (GE). Different uppercase letters show significant differences between the two experimental years within each crop. Different lowercase letters show significant differences between crops within each system and experimental year $(\mathrm{p}<0.05)$.

\begin{tabular}{|c|c|c|c|c|c|c|c|c|c|c|c|c|c|}
\hline \multirow[b]{2}{*}{ System } & \multirow[b]{2}{*}{ Crop } & \multicolumn{7}{|c|}{ First Experimental Year } & \multicolumn{5}{|c|}{ Second Experimental Year } \\
\hline & & $\begin{array}{c}\mathrm{N}_{2} \mathrm{O} \\
{[\mathrm{kg} \mathrm{N} \mathrm{ha}} \\
\end{array}$ & $\underset{\left[\mathrm{kg} \mathrm{Cha}^{-1}\right]}{\mathrm{CH}_{4}}$ & $\begin{array}{c}\mathrm{GWP} \\
{\left[\mathrm{kg} \mathrm{CO}_{2 \mathrm{eq}} \mathrm{ha}^{-1}\right]}\end{array}$ & $\begin{array}{c}\text { Yield } \\
\text { [t DM ha } \mathrm{h}^{-1} \text { ] }\end{array}$ & $\begin{array}{c}\text { Yield } \\
{\left[\mathrm{GE} \mathrm{ha}^{-1}\right]}\end{array}$ & $\begin{array}{c}\mathrm{PCF}_{\mathrm{NON}-\mathrm{CO} 2} \\
{\left[\mathrm{~kg} \mathrm{CO}_{2 \mathrm{eq}} \mathrm{GE}^{-1}\right]}\end{array}$ & $\begin{array}{c}\mathrm{N}_{2} \mathrm{O} \\
{\left[\mathrm{kg} \mathrm{N} \mathrm{ha}^{-1}\right]}\end{array}$ & $\underset{\left[\mathrm{kg} \mathrm{Cha}^{-1}\right]}{\mathrm{CH}_{4}}$ & $\begin{array}{c}\mathrm{GWP} \\
{\left[\mathrm{kg} \mathrm{CO}_{2 \mathrm{eq}} \mathrm{ha}^{-1}\right]}\end{array}$ & $\begin{array}{c}\text { Yield } \\
\text { [t DM ha-1] }\end{array}$ & $\begin{array}{c}\text { Yield } \\
{\left[\mathrm{GE} \mathrm{ha}^{-1}\right]}\end{array}$ & $\begin{array}{c}\mathrm{PCF}_{\mathrm{NON}-\mathrm{CO} 2} \\
{\left[\mathrm{~kg} \mathrm{CO}_{2 \mathrm{eq}}\right.} \\
\left.\mathrm{GE}^{-1}\right]\end{array}$ \\
\hline \multirow{4}{*}{ Organic-low-BNF } & Grass-clover & $0.2^{\mathrm{Ab}}$ & $-0.1^{\mathrm{Aa}}$ & $79.5^{\mathrm{Ab}}$ & 7.1 & 40.9 & $1.9^{\mathrm{Ac}}$ & $0.3^{\mathrm{Ab}}$ & $-0.3^{\mathrm{Ba}}$ & $113.6^{\mathrm{Ab}}$ & 6.7 & 38.7 & $2.9^{\mathrm{Ab}}$ \\
\hline & Winter wheat & $0.9^{\mathrm{Aa}}$ & $-0.3^{\mathrm{Aa}}$ & $363.2^{\text {Аa }}$ & 3.2 & 33.6 & $10.8^{\mathrm{Aa}}$ & $2.3^{\mathrm{Aa}}$ & -0.1 Ba & 953.2 Аа & 3.0 & 31.1 & $30.6^{\mathrm{Aa}}$ \\
\hline & Winter rye & $0.5^{\mathrm{Aa}}$ & $-0.3^{\mathrm{Aa}}$ & $196.8^{\text {Аа }}$ & 4.1 & 41.4 & $4.8^{\mathrm{Ab}}$ & $0.4^{\mathrm{Ab}}$ & $-0.2 \mathrm{Aa}$ & $159.0^{\mathrm{Ab}}$ & 4.4 & 44.4 & $3.6^{\mathrm{Ab}}$ \\
\hline & Summer oats & $1.0^{\mathrm{Aa}}$ & $-0.1^{\mathrm{Ab}}$ & $412.3^{\mathrm{Aa}}$ & 3.1 & 25.9 & 15.9 Аa & $0.6^{\mathrm{Ab}}$ & $-0.1^{\mathrm{Aa}}$ & $245.9 \mathrm{Ab}$ & 3.7 & 31.1 & $7.9^{\mathrm{Ab}}$ \\
\hline \multirow{5}{*}{ Organic-semi-BNF } & Grass-clover & $0.0 \mathrm{Ad}$ & $-0.1^{\mathrm{Ac}}$ & $12.9^{\mathrm{Ad}}$ & 6.3 & 36.4 & $0.4^{\mathrm{Ad}}$ & $0.2^{\mathrm{Bc}}$ & $-0.2^{\mathrm{Aa}}$ & $75.7^{\mathrm{Bc}}$ & 5.8 & 33.4 & $2.3^{\mathrm{Bc}}$ \\
\hline & Winter wheat & $1.1^{\mathrm{Aa}}$ & $-0.5^{\mathrm{Aa}}$ & $439 \mathrm{Aa}$ & 3.5 & 36.8 & $11.9^{\mathrm{Aa}}$ & $1.7 \mathrm{Aa}$ & -0.2 Ва & $699.8 \mathrm{Aa}$ & 4.0 & 41.6 & $16.8^{\mathrm{Aa}}$ \\
\hline & Winter rye & $0.5 \mathrm{Ab}$ & -0.3 Aabc & $196.8^{\mathrm{Ab}}$ & 4.1 & 41.4 & $4.8^{\mathrm{Ab}}$ & $0.7^{\mathrm{Ab}}$ & $-0.2^{\mathrm{Aa}}$ & $283.8^{\mathrm{Ab}}$ & 4.9 & 49.5 & $5.7^{\mathrm{Ab}}$ \\
\hline & Spring field peas & $0.4^{\mathrm{Aab}}$ & $-0.1 \mathrm{Aab}$ & $162.7 \mathrm{Abc}$ & 3.5 & 36.1 & $4.5 \mathrm{Aab}$ & 1.6 Aabc & $-0.1 \mathrm{Aa}$ & 661.9 Aabc & 3.1 & 32.2 & 20.6 Aabc \\
\hline & Winter rye & $0.3^{\mathrm{Ac}}$ & $-0.3^{\mathrm{Ab}}$ & $113.6^{\mathrm{Ac}}$ & 4.6 & 46.0 & $2.5^{\mathrm{Ac}}$ & $0.4^{\mathrm{Abc}}$ & -0.1 Ba & $162.7 \mathrm{Abc}$ & 3.0 & 30.3 & $5.4^{\mathrm{Ab}}$ \\
\hline \multirow{5}{*}{ Conven-tional } & Oil seed rape & $2.6^{\mathrm{Ab}}$ & $-0.2^{\mathrm{Aab}}$ & $1074.3^{\mathrm{Ab}}$ & 4.3 & 55.9 & $19.2 \mathrm{Aa}$ & $2.6^{\mathrm{Aa}}$ & $-0.4^{\mathrm{Bab}}$ & $1066.8^{\mathrm{Aa}}$ & 4.9 & 63.7 & $16.7^{\mathrm{Aa}}$ \\
\hline & Winter wheat & $0.9^{\mathrm{Ac}}$ & $-0.3^{\mathrm{Aa}}$ & $363.2 \mathrm{Ac}$ & 10.8 & 112.3 & $3.2^{\mathrm{Ac}}$ & $1.7^{\mathrm{Bb}}$ & $-0.2^{\mathrm{Ac}}$ & $699.8^{\mathrm{Bb}}$ & 11.4 & 118.6 & $5.9^{\mathrm{Bb}}$ \\
\hline & Winter wheat & $2.7 \mathrm{Ab}$ & $-0.1^{\mathrm{Ab}}$ & $1119.6^{\mathrm{Ab}}$ & 9.8 & 101.8 & $11.0^{\mathrm{Ab}}$ & $0.7^{\mathrm{Bc}}$ & $-0.2 \mathrm{Aac}$ & $283.8^{\mathrm{BC}}$ & 10.3 & 107.1 & $2.6^{\mathrm{Bc}}$ \\
\hline & Sugar beet & $2.0^{\mathrm{Aab}}$ & $-0.2^{\text {Aab }}$ & 824.6 Aabc & 75.0 & 172.5 & $4.8^{\mathrm{Ac}}$ & $1.6^{\mathrm{Ab}}$ & $-0.2^{\mathrm{Ac}}$ & $658.2^{\mathrm{Ab}}$ & 89.0 & 204.7 & $3.2 \mathrm{Ac}$ \\
\hline & Winter wheat & $4.1 \mathrm{Aa}$ & $-0.3^{\mathrm{Aa}}$ & $1694.6^{\mathrm{Aa}}$ & 9.8 & 101.8 & $16.6^{\mathrm{Aa}}$ & $1.7^{\mathrm{Bb}}$ & -0.5 Ва & $688.6^{\mathrm{Bb}}$ & 11.2 & 116.5 & $5.9^{\mathrm{Bb}}$ \\
\hline Grass-land & & 0.2 & -0.1 & 82.2 & 2.4 & 14.2 & 5.8 & 0.3 & -0.1 & 122 & 2.4 & 14.1 & 8.6 \\
\hline Beech forest & & 0.2 & -3.9 & -51.3 & & - & - & 0.5 & -2.5 & 114 & & - & - \\
\hline
\end{tabular}


The amounts of $\mathrm{N}$ input, $\mathrm{N}$ balance and the $\mathrm{C} / \mathrm{N}$ ratio were statistically tested against amounts of released annual $\mathrm{N}_{2} \mathrm{O}$ emissions. In general, the conventional crop rotations showed higher $\mathrm{N}$ inputs and positive $\mathrm{N}$ balance in all crops and experimental years. With regard to the $\mathrm{N}$ balance levels in the organic systems, the values in the subsequent crop after cereals were negative. The highest surpluses were measured in the winter wheat after incorporation of the preceding grass-clover swards.

The regression analysis showed, on average, a positive linear relationship between $\mathrm{N}$ input and annual $\mathrm{N}_{2} \mathrm{O}$ emissions for the tested arable systems (intercept: 0.44, slope:0.007, $\mathrm{R}^{2}=0.6, \mathrm{p}<0.01$ ). The relationship of $\mathrm{N}$ surplus on annual $\mathrm{N}_{2} \mathrm{O}$ emissions was also significant (intercept: 0.86 , slope:0.01, $\mathrm{R}^{2}=0.6, \mathrm{p}<0.01$ ). Comparing this $\mathrm{N}$ surplus to the $\mathrm{N}$ surplus of the preceding crop, the effect of the preceding crop was a more reliable indicator to predict annual $\mathrm{N}_{2} \mathrm{O}$ emissions (intercept: 0.4 , slope: $0.03, \mathrm{R}^{2}=0.8, \mathrm{p}<0.01$ ) (Figure 5). This fact was also confirmed by a strong effect of the $\mathrm{C} / \mathrm{N}$ ratio of plant residues on the measured $\mathrm{N}_{2} \mathrm{O}$ losses in the subsequent months after incorporation into soil. The measured emissions of $\mathrm{N}_{2} \mathrm{O}$ declined exponentially, with increasing $\mathrm{C} / \mathrm{N}$ ratio from incorporated straw and stubble residues (Figure 6). On average, for the different arable crop rotations, the $\mathrm{C} / \mathrm{N}$ ratios of crop residues differed in the order of conventional (65 (SE 5.9)) < organic-semi-BNF (102 (SE 6.4)) < organic-low-BNF (125 (SE 5.9)) ( $\mathrm{p}<0.05)$.
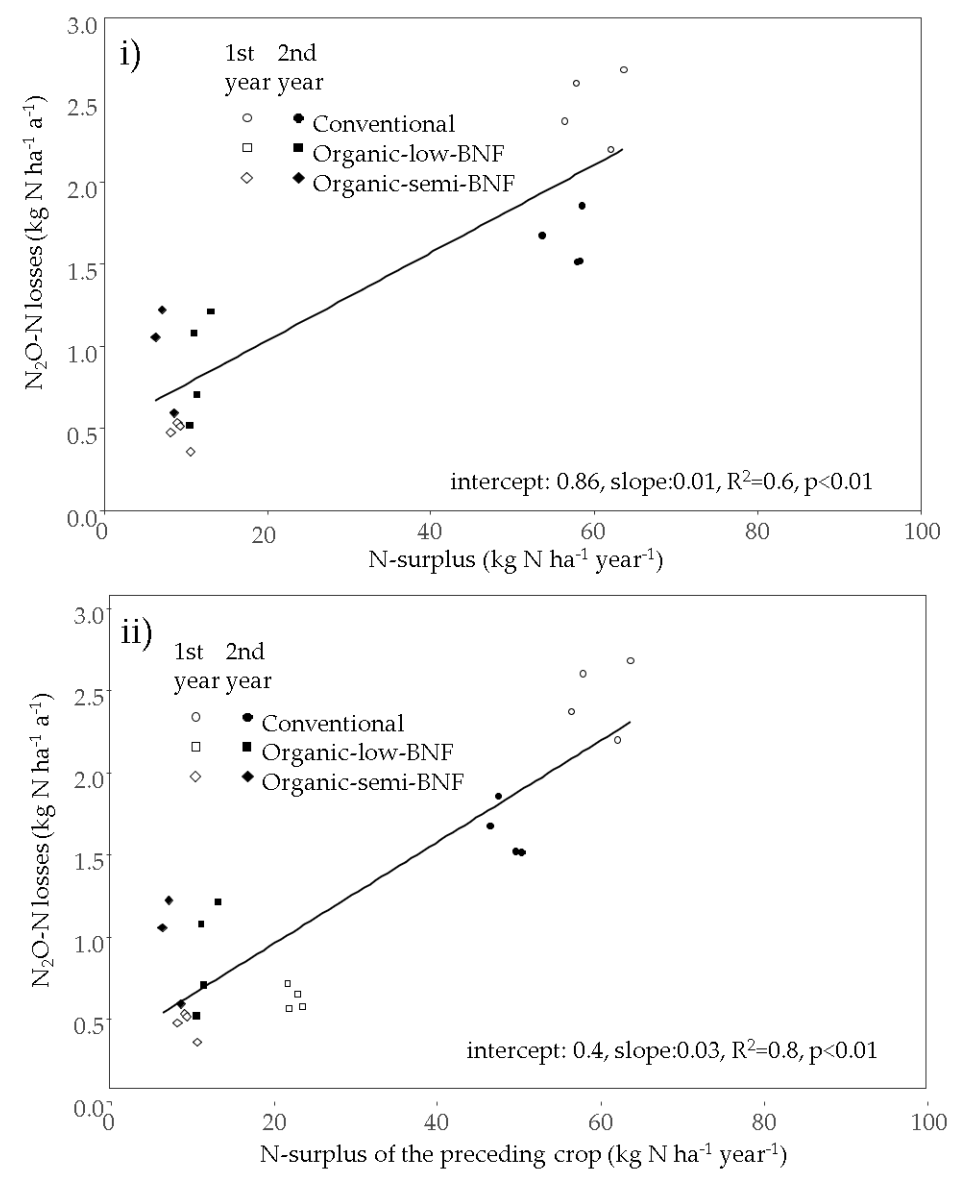

Figure 5. The relationship between annual $\mathrm{N}_{2} \mathrm{O}-\mathrm{N}$ emissions and (i) $\mathrm{N}$ surplus, as well as (ii) $\mathrm{N}$ surplus of the preceding crop, average of the different crop rotations.

According to the performed regression analysis, the emission factor for $\mathrm{N}$ inputs was $0.7 \%$. However, taking the $\mathrm{N}$ balance of the main crop and the preceding crop into account, the emissions factors are $1 \%$ and $3 \%$ of each $\mathrm{kg} \mathrm{N}$ in surplus, respectively.

For $\mathrm{CH}_{4}$, the tested arable systems showed only negligible exchange (values close to zero), or they acted as a sink. The measured sink of the beech forest, as a natural reference ecosystem, exceeded those 
of the agriculturally managed systems. Thus, annual accumulated emissions showed a notable $\mathrm{CH}_{4}$ sink capacity of 3.9 and $2.5 \mathrm{~kg} \mathrm{CH}_{4}-\mathrm{C} \mathrm{ha}^{-1}$ in the first and second year, respectively.

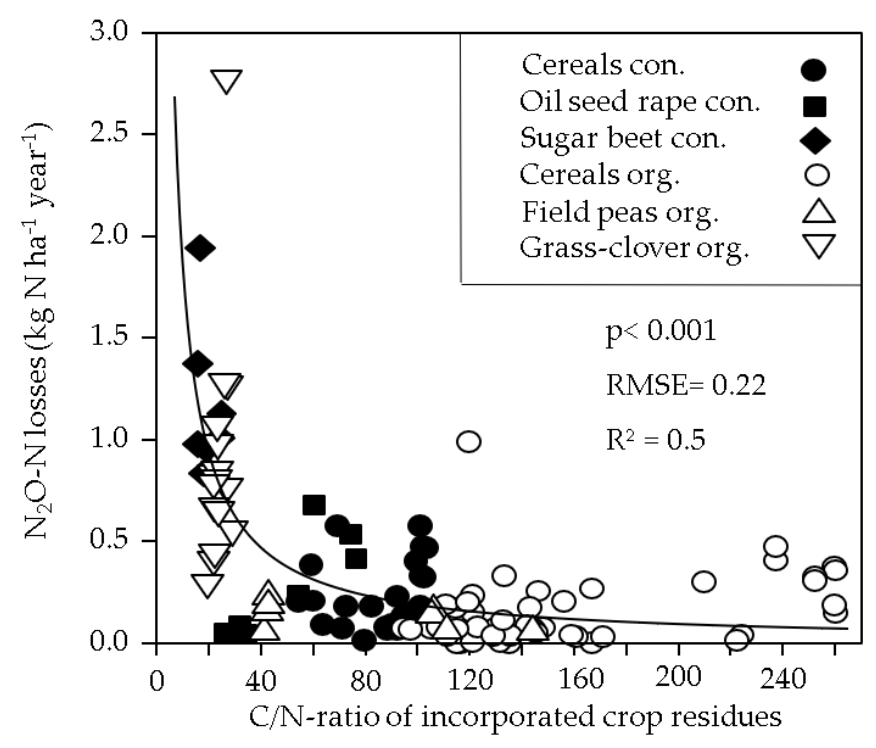

Figure 6. Relationship between $\mathrm{C} / \mathrm{N}$ ratio of incorporated aboveground crop residues and $\mathrm{N} 2 \mathrm{O}-\mathrm{N}$ emissions for a period of 4 months (Oct-Feb) post-harvest: [ $\mathrm{kg} \mathrm{N}_{2} \mathrm{O}-\mathrm{N} \mathrm{ha}{ }^{-1}$ year $^{-1}=18.8 * 1 / \mathrm{CN}$-ratio].

\subsection{Crop Yields and Yield-Related GHG Emissions}

The crop yields of the organic crop rotations were lower in both experimental years compared with the conventional farming system. On average, the GE output from organic farming was 0.32 of the yield of the conventional system. The total average yields of the two organic systems were similar for dry matter but slightly higher for energy expressed as GE in the organic-semi-BNF ( 38 vs. $36 \mathrm{GE}_{\text {year }}{ }^{-1}$ ). Within the organically managed systems the grass-clover leys showed the lowest emissions per GE. Slightly higher emissions of $5 \mathrm{~kg} \mathrm{CO}_{2} \mathrm{e} \mathrm{GE}^{-1}$ were observed for winter rye. A higher $\mathrm{PCF}_{\mathrm{NON}-\mathrm{CO} 2}$ was found in the organically managed winter wheat due to the effect of grass-clover removal as a preceding crop. Due to the relatively low yield level of spring oat and spring field peas, the product-related emissions of these crops exceeded all other crops in the organically managed systems. In the conventional system the highest $\mathrm{PCF}_{\mathrm{NON}-\mathrm{CO} 2}$ values were found in oilseed rape and winter wheat with sugar beet as a preceding crop (Table 3 ).

The annual emissions of $\mathrm{CO}_{2 \text { eq }}$ averaged over each of the whole crop rotations are given in Table 4. All the studied agricultural systems were sources of GHG emissions, whereas the beech forest functioned as a sink for $\mathrm{CO}_{2 \text { eq }}$ because of its negligible $\mathrm{N}_{2} \mathrm{O}$ losses and significant $\mathrm{CH}_{4}$ consumption during the first year. The highest $\mathrm{CO}_{2 \text { eq }}$ emissions were observed for the conventional system, whereas emissions from the two organically managed systems, on average over the two years, were 0.35 that of the conventional system. The differences in the $\mathrm{PCF}_{\mathrm{NON}-\mathrm{CO} 2}$ values showed no clear trend between the different systems. Both the organic-low-BNF and conventional cropping systems showed differences between the experimental years, but these were not different between organic-semi-BNF and grassland. During the first experimental year, the $\mathrm{PCF}_{\mathrm{NON}-\mathrm{CO} 2}$ values were lowest for the reference grassland and highest for conventional farming. However, during the second year $\mathrm{PCF}_{\mathrm{NON}-\mathrm{CO} 2}$ was lowest for conventional farming and highest for organic-low-BNF, with no differences to organic-semi-BNF (Table 4). Thus, comparing the two organic systems, the organic-semi-BNF showed an advantage, with either lower emissions than the organic-low-BNF or no differences to the conventional system. 
Table 4. Average global warming potential (GWP) and product carbon footprint ( $\left.\mathrm{PCF}_{\mathrm{NON}-\mathrm{CO} 2}\right)$ per system and experimental year (first and second). Yields were estimated at farm level by weighing the harvested crops. Product carbon footprints were derived from GWP and grain equivalents (GE). Different uppercase letters show significant differences between the two experimental years within each system. Different lowercase letters show significant differences between the systems within each experimental year. $(\mathrm{p}<0.05)$. Standard errors $(\mathrm{SE})$ are shown in brackets.

\begin{tabular}{|c|c|c|c|c|}
\hline & \multicolumn{2}{|c|}{ First Experimental Year } & \multicolumn{2}{|c|}{ Second Experimental Year } \\
\hline System & GWP $\left[\mathrm{kg} \mathrm{CO} \mathrm{Ceq}_{\left.2 a^{-1}\right]}\right.$ & $\mathrm{PCF}_{\mathrm{NON}-\mathrm{CO} 2}\left[\mathrm{~kg} \mathrm{GE}^{-1}\right]$ & GWP $\left[\mathrm{kg} \mathrm{CO} \mathrm{Coq} \mathrm{ha}^{-1}\right]$ & $\mathrm{PCF}_{\mathrm{NON}-\mathrm{CO} 2}\left[\mathrm{~kg} \mathrm{GE}^{-1}\right]$ \\
\hline Organic-low-BNF & $263.0(24.1) \AA$ & $8.4(0.58)^{\mathrm{Ab}}$ & $367.9(66.5)^{\AA} \AA$ & $11.3(2.13)^{\text {Aab }}$ \\
\hline Organic-semi-BNF & $185.0(10.5) \mathrm{Ac}$ & $4.8(0.28) \mathrm{Ac}$ & $376.8(98.4)^{\mathrm{Bb}}$ & $10.1(3.17) \mathrm{Ba}$ \\
\hline Conventional & $1015.3(60.1) \mathrm{Aa}$ & $11.0(0.44)$ Аa & $679.4(31.5) \mathrm{Ba}$ & $6.9(0.28)^{\mathrm{Bb}}$ \\
\hline Grassland & $82.2(46.4)$ Acd & 5.8 (3.3) Aabc & $122.1(29.2) \mathrm{Ac}$ & $8.6(2.05)$ Aab \\
\hline Beech forest & $-51.3(39.8) \mathrm{Ad}$ & & $114.9(8.9) \mathrm{Ac}$ & \\
\hline
\end{tabular}

\section{Discussion}

\subsection{GHG-Fluxes}

In general, there were differences between the investigated organic and conventional systems in crop rotations, type of grown crops, and the intensity of $\mathrm{N}$ input. Even though the conventional system was managed in accordance with the German fertilizer ordinance (2017), it had a substantially higher $\mathrm{N}$ input than the organic systems and reference land-use systems. It is widely accepted that the $\mathrm{N}$ input from synthetic fertilizers and manure is the main source of $\mathrm{N}_{2} \mathrm{O}$ emissions from agricultural soils $[28,29]$. The daily $\mathrm{N}_{2} \mathrm{O}$ flux rates and the measured emission peaks generally followed the fertilizer applications, which is consistent with similar previous findings [10,44-46]. This also accords with GHG inventories using $\mathrm{N}$ input as the main variable to calculate direct $\mathrm{N}_{2} \mathrm{O}$ emissions from agricultural soils. However, although the standard emission factor used was $1 \%$ for each $\mathrm{kg}$ of $\mathrm{N}$-applied, we found emission factors of 0.2 and $1.8 \%$ in the conventional crop rotation. This may be explained partly by differences between different types of $\mathrm{N}$ fertilizer [47,48], as greater $\mathrm{N}_{2} \mathrm{O}$ peaks after application of manure, in comparison with applications of mineral $\mathrm{N}$ fertilizer, are likely $[46,49]$ due to the higher availability of easily accessible carbon triggering high $\mathrm{N}_{2} \mathrm{O}$ peaks from soil denitrifiers, when oxygen is limiting. Other authors have also concluded that calculations of $\mathrm{N}_{2} \mathrm{O}$ emissions based on $\mathrm{N}$-fertilizer input are not reliable, as better correlations exist between $\mathrm{N}$ surplus and $\mathrm{N}_{2} \mathrm{O}$ emissions [28]. Hence, to reduce $\mathrm{N}_{2} \mathrm{O}$ emissions, the aim at the farm scale should be to increase $\mathrm{N}$ use efficiency [32]. This aim was also supported by the results of our study, with a significant correlation between $\mathrm{N}_{2} \mathrm{O}$ emissions and the calculated $\mathrm{N}$ balance of the preceding crop showing a better relationship than only the $\mathrm{N}$ input. In addition to the fertilizer application and its management, the potential mineralizable $\mathrm{N}$ from crop residues is a further main driver of $\mathrm{N}_{2} \mathrm{O}$ release in soil. This was particularly evident in the conventional systems for winter oilseed rape, as the $\mathrm{N}$ removed in the harvested seeds is low and the crop residues are within a narrow $\mathrm{C} / \mathrm{N}$ ratio. This situation is also true after sugar beet harvest, due to the narrow $\mathrm{C} / \mathrm{N}$ ratio of the leaves and tops with high moisture content compared with cereal straw and rape straw [50]. In the case of cereal straw, low $\mathrm{N}_{2} \mathrm{O}$ emissions can be further explained by temporary immobilization of soil $\mathrm{N}$ due to the high $\mathrm{C} / \mathrm{N}$ ratios. This may have occurred in the case of incorporated cereal straw material, potentially explaining the comparatively low emissions of $\mathrm{N}_{2} \mathrm{O}$.

In the organic systems, grass-clover swards are utilized as the main source of $\mathrm{N}$ [32,51], but with different findings of the effect on $\mathrm{N}_{2} \mathrm{O}$ emissions. According to the results of Benoit et al. [52], intact legume swards were shown to be the crops with the lowest $\mathrm{N}_{2} \mathrm{O}$ emissions in agricultural systems because of a high potential for effective $\mathrm{N}$ cycling [53]. However, in the year of grassland removal, high $\mathrm{N}$ surpluses and annual $\mathrm{N}_{2} \mathrm{O}$ emissions were measured in the following crop of winter wheat.

Agriculture has also been identified as a major anthropogenic source of $\mathrm{CH}_{4}$ due to microbial activity in ruminant digestion and in livestock slurry, while wetlands are considered as a major natural source of emission [54]. However, under aerobic conditions, soils under agricultural management 
act as a sink for $\mathrm{CH}_{4}[55,56]$. According to Boeckx and Van Cleemput [55], arable soils have a lower mean $\mathrm{CH}_{4}$ sink function $\left(-1.5 \mathrm{~kg} \mathrm{CH}_{4}\right.$ ha $^{-1}$ year $\left.{ }^{-1}\right)$ than grassland soils $\left(-2.5 \mathrm{~kg} \mathrm{CH}_{4} \mathrm{ha}^{-1}\right.$ year $\left.^{-1}\right)$. Mineral $\mathrm{N}$ fertilizer application can also have a negative effect on the $\mathrm{CH}_{4}$ oxidation capacity of arable soils [57]. The highest $\mathrm{CH}_{4}$ oxidation rates have been reported for near-natural forest soils [25,58,59]. In support of this, in our study the beech-forest showed the highest average $\mathrm{CH}_{4}$ sink capacity. However, our findings did not confirm higher $\mathrm{CH}_{4}$ uptake of grassland soils compared with the arable systems, and only a minimal higher $\mathrm{CH}_{4}$ oxidation capacity of the unfertilized organic rotations.

\subsection{Crop Yields and Yield-Related GHG Emissions}

In the conventional system the relatively high but site-typical application rate of mineral fertilizers, combined with appropriate plant protection measures, led to three-fold higher crop yields compared with the organic systems. Such distinct differences in yields have generally not been documented in other studies $[35,60]$. Lower yields from organic systems are due partly to lower supplies of nutrients, including possible deficits of phosphorus, potassium, magnesium and micronutrients, and the comparatively lower soil $\mathrm{pH}$ values of the organically managed fields (see Supplementary Table S1). Nutrient deficits are a particular problem in pure arable organic systems without animal husbandry and external $\mathrm{N}$ supplies, leading to negative $\mathrm{N}$ balance levels and decreasing soil $\mathrm{N}$ stocks.

In the context of increasing demand for organic farming products and addressing the environmental problems associated with agriculture, including the challenges of climate change, there is a need to also consider emissions per unit of product when conventional and organic farming systems are compared [61]. This, and the concept of sustainable intensification in agriculture, are today often considered with the twin aims of maximizing the production of agricultural goods and minimizing the negative impacts on the environment [62]. In the present study, we considered the product unit (grain equivalents) as an appropriate measure relevant at a global environmental scale, and here we found that the three systems showed comparable values. Similar results were reported by Flessa et al. [63], where organic farming did not result in different emissions per unit of crop yield. Controversially, in a meta-analysis, Skinner et al. [23] found $29 \%$ higher yield-related $\mathrm{N}_{2} \mathrm{O}$ emissions for arable organic systems. Also, Chirindaa et al. [64] and Knudsen et al. [65] showed higher product-related $\mathrm{N}_{2} \mathrm{O}$ emissions for organic arable systems on average for all investigated crop rotations. However, comparisons in the literature between organic and conventional arable production depend strongly on the types of crops under investigation $[29,31,52,64]$ with different crops affecting yield-related emissions differently. Further, in the present study, we also included non-food crops in the analysis, in this case red clover as fodder legumes, and, as they were sold, they have a market value as a product.

Beyond the measured field-level emissions, the different systems should be further evaluated in terms of a full lifecycle assessment (LCA) analysis that also includes any emissions produced from external resources [65]. With regard to our field measurement results and the expected (though unmeasured) higher energy use in the conventional system, we assume that the tested organic systems would show further net benefit, relative to intensive conventional systems, under the perspective of an LCA analysis. However, other impact categories like eutrophication, acidification and cumulative energy use should be taken into account in order to avoid negative implication on other environmental resources. In our study, associated research groups from the project group Hof Ritzerau identified significant benefits from the conversion to organic farming over a ten-year period, e.g., regarding soil biota and birds $[66,67]$. Thus, when modelling options for optimized land use systems in terms of sustainable intensification on high fertility arable soils, an optimal share of the area under organic farming has to be predicted in order to ensure long-term ecosystem functioning in landscapes. Finally, the economic consequences for producers, and for wider society and its welfare, also need to be considered in relation to any large-scale land-use change, either to organic farming or other extensive land-use systems like grassland and forestry. 


\subsection{Further Mitigation Potential}

An important finding of this study was the increased $\mathrm{N}_{2} \mathrm{O}$ emissions after soil tillage in arable systems. This was mainly controlled by the chemical composition of the crop residues, particularly when narrow $\mathrm{C} / \mathrm{N}$ ratios were present, and was clearly shown over a wide range of arable crops and use intensities. A serious weakness in the conventional as well as the two organic systems was the inefficient use of nutrients in crop residues, as well as the failure not to take mineralizable $\mathrm{N}$ into account for fertilizer planning and to ensure optimal timing of ploughing in the grass-legume ley phase. Thus, further mitigation could be achieved through reduced input of mineral $\mathrm{N}$ fertilizer in the conventional systems. If organic fertilizers are applied, as manure or digestates, their $\mathrm{N}$ contents should be also taken into account for optimal $\mathrm{N}$ management strategies to avoid highly positive $\mathrm{N}$ surpluses. With regards to the replacement of the grass-clover ley in the rotation, one efficient measure would be to postpone ploughing until spring to reduce emissions, as high $\mathrm{N}_{2} \mathrm{O}$ fluxes occur during winter at locations where freeze-thaw cycles are expected [30]. Generally, there is a need to reduce $\mathrm{N}_{2} \mathrm{O}$ emissions in organic farming systems after the incorporation of $\mathrm{N}$ rich crop residues [31] such as those which occur after the replacement of a grass-clover ley. Organic arable farms especially should seek opportunities to enter into cooperation agreements with livestock farms to exchange herbage harvested from grass-clover crops (as silage bales) for livestock manure. This would not only support increased yields but also help maintain soil fertility. Another option is to remove the mown grass-clover biomass for biogas production and apply the digestate to the soil the following spring. Möller et al. [68] concluded that this option leads to additional energy yields, a lower risk of nitrate leaching, and lower $\mathrm{N}_{2} \mathrm{O}$ emissions compared with swards that are just mown and mulched. Manure application has been shown to be one of the main factors in arable organic farming needed to generate competitive crop yields. Nevertheless, the use of organic fertilizer can cause additional $\mathrm{N}_{2} \mathrm{O}$ emissions [65], and, thus, has to be further evaluated.

Finally, the aim of all arable systems should be to maintain or increase crop yields without causing additional environmental problems [69,70]. In this context, the key factor in organic farming is an efficient method of converting the grass-clover ley phase for a subsequent crop, without significant $\mathrm{N}$ losses, and efficiently managing the use of legumes in the crop rotation. In our study, the use of $25 \%$ of legumes in the arable crop rotation was not enough to achieve adequate yield to compete with the arable conventional systems in terms of emissions per product unit. This was only given with a share of $40 \%$ legumes in the crop rotation.

\section{Conclusions}

Organically managed arable rotations showed advantages in comparison with intensive conventional arable cropping through reduced GHG emissions and N surplus expressed on a per-ha basis. Hence, an increase in the area of organic farming on farmland with arable rotation systems is a suitable measure for reducing GHG emissions and nutrient loads at a national or landscape level. On the global scale, however, emissions have to be considered also on a per-unit of product basis, as climate is a global environmental good. Taking that into account, and the strongly limited productivity of organic all arable farming as well, it becomes evident that improved strategies beyond specialized conventional and organic approaches focusing on mixed farming systems with enhanced eco-efficiency are needed to ensure both global food demand and ecosystem services.

Supplementary Materials: The following are available online at http://www.mdpi.com/2071-1050/12/8/3240/s1, Figure S1: Daily $\mathrm{N}_{2} \mathrm{O}$ - (black line and dots) and $\mathrm{CH}_{4}$-fluxes (grey line and dots) of the reference systems (grassland and beech forest) during the study period (October 2012-October 2014). The grey background represents periods with mean daily temperatures below $0{ }^{\circ} \mathrm{C}$. Mean values are shown $(\mathrm{n}=4)$., Table S1: Observed systems and crops within the different arable rotations, soil properties of the experimental sites, selected agronomic practices and sowing date during the experimental years (1st year: October 2012-October 2013, 2nd year: October 2013-October 2014).

Author Contributions: Conceptualization, R.L. and F.T.; methodology, T.R.; software, C.K.; validation, L.B., C.K. and T.R.; formal analysis, L.B.; investigation, L.B.; resources, F.T.; data curation, C.K.; writing-original draft 
preparation, L.B.; writing—review and editing, T.R.; visualization, C.K.; supervision, R.L.; project administration, F.T.; funding acquisition, F.T. All authors have read and agreed to the published version of the manuscript.

Funding: The scientific investigations are kindly sponsored by the owner of Hof Ritzerau, Günther Fielmann.

Acknowledgments: We thank, A. Stallbaum, T. Bönisch, H. Hagedorn, J. Radtke, J. Rudelt, V. Benz and K. Helmich for their assistance during the field measurements. We also thank the anonymous reviewers for their comments on an earlier version of this article. We acknowledge financial support by DFG within the funding programme Open Access Publishing.

Conflicts of Interest: The authors declare no conflict of interest.

\section{References}

1. IPCC. Contribution of Working Groups I, II and III to the Fifth Assessment Report of the Intergovernmental Panel on Climate Change; Climate Change 2014: Synthesis Report; IPCC: Geneva, Switzerland, 2014.

2. Smith, K.A.; Ball, T.; Conen, F.; Dobbie, K.E.; Massheder, J.; Rey, A. Exchange of greenhouse gases between soil and atmosphere: Interactions of soil physical factors and biological processes. Eur. J. Soil Sci. 2003, 54, 779-791. [CrossRef]

3. Cicerone, R.J. Changes in Stratospheric Ozone. Science 1987, 237, 35-42. [CrossRef]

4. Ravishankara, A.R.; Daniel, J.S.; Portmann, R.W. Nitrous Oxide $\left(\mathrm{N}_{2} \mathrm{O}\right)$ : The Dominant Ozone-Depleting Substance Emitted in the 21st Century. Science 2009, 326, 123-125. [CrossRef]

5. Thomson, A.J.; Giannopoulos, G.; Pretty, J.; Baggs, E.M.; Richardson, D.J. Biological sources and sinks of nitrous oxide and strategies to mitigate emissions. Philos. Trans. R. Soc. B Biol. Sci. 2012, 367, 1157-1168. [CrossRef]

6. Fowler, D.; Coyle, M.; Skiba, U.; Sutton, M.A.; Cape, J.N.; Reis, S.; Sheppard, L.J.; Jenkins, A.; Grizzetti, B.; Galloway, J.N.; et al. The global nitrogen cycle in the twenty-first century. Philos. Trans. R. Soc. B 2013, 368, 20130164. [CrossRef]

7. Dobbie, K.E.; Smith, K.A. Nitrous oxide emission factors for agricultural soils in Great Britain: The impact of soil water-filled pore space and other controlling variables. Glob. Chang. Biol. 2003, 9, 204-218. [CrossRef]

8. Flessa, H.; Pfau, W.; Dörsch, P.; Beese, F. The influence of nitrate and ammonium fertilization on $\mathrm{N}_{2} \mathrm{O}$ release and $\mathrm{CH} 4$ uptake of a well-drained topsoil demonstrated by a soil microcosm experiment. Zeitschrift Pflanzenernährung Bodenkunde 1996, 159, 499-503. [CrossRef]

9. Henault, C.; Devis, X.; Page, S.; Justes, E.; Reau, R.; Germon, J.C. Nitrous oxide emissions under different soil and land management conditions. Biol. Fertil. Soils 1998, 26, 199-207. [CrossRef]

10. Kaiser, E.A.; Kohrs, K.; Kücke, M.; Schnug, E.; Munch, J.C.; Heinemeyer, O. Nitrous oxide release from arable soil: Importance of perennial forage crops. Biol. Fertil. Soils 1998, 28, 36-43. [CrossRef]

11. Stevens, R.J.; Laughlin, R.J.; Burns, L.C.; Arah, J.R.M.; Hood, R.C. Measuring the contributions of nitrification and denitrification to the flux of nitrous oxide from soil. Soil Biol. Biochem. 1997, 29, 139-151. [CrossRef]

12. Dechow, R.; Freibauer, A. Assessment of German nitrous oxide emissions using empirical modelling approaches. Nutr. Cycl. Agroecosyst. 2011, 91, 235-254. [CrossRef]

13. Baggs, E.M.; Stevenson, M.; Pihlatie, M.; Regar, A.; Cook, H.; Cadisch, G. Nitrous oxide emissions following application of residues and fertiliser under zero and conventional tillage. Plant Soil 2003, 254, 361-370. [CrossRef]

14. Ruser, R.; Flessa, H.; Russow, R.; Schmidt, G.; Buegger, F.; Munch, J.C. Emission of $\mathrm{N}_{2} \mathrm{O}, \mathrm{N}_{2}$ and $\mathrm{CO}_{2}$ from soil fertilized with nitrate: Effect of compaction, soil moisture and rewetting. Soil Biol. Biochem. 2006, 38, $263-274$. [CrossRef]

15. Šimek, M.; Jíšová, L.; Hopkins, D.W. What is the so-called optimum $\mathrm{pH}$ for denitrification in soil? Soil Biol. Biochem. 2002, 34, 1227-1234. [CrossRef]

16. Breuer, L.; Butterbach-Bahl, K. Local temperature optimum of $\mathrm{N}_{2} \mathrm{O}$ production rates in tropical rain forest soils of Australia. Soil Res. 2005, 43, 689-694. [CrossRef]

17. Dobbie, K.E.; Smith, K.A. The effects of temperature, water-filled pore space and land use on N2O emissions from an imperfectly drained gleysol. Eur. J. Soil Sci. 2001, 52, 667-673. [CrossRef]

18. Mosier, A.R.; Duxbury, J.M.; Freney, J.R.; Heinemeyer, O.; Minami, K. Assessing and Mitigating N2O Emissions from Agricultural Soils. Clim. Chang. 1998, 40, 7-38. [CrossRef] 
19. Bouwman, A.F. Direct emission of nitrous oxide from agricultural soils. Nutr. Cycl. Agroecosyst. 1996, 46, 53-70. [CrossRef]

20. Kaiser, E.A.; Kohrs, K.; Kücke, M.; Schnug, E.; Heinemeyer, O.; Munch, J.C. Nitrous oxide release from arable soil: Importance of N-fertilization, crops and temporal variation. Soil Biol. Biochem. 1998, 30, 1553-1563. [CrossRef]

21. Velthof, G.L.; Oenema, O. Nitrous oxide emission from dairy farming systems in the Netherlands. Neth. J. Agric. Sci. 1997, 45, 347-360.

22. Lebender, U.; Senbayram, M.; Lammel, J.; Kuhlmann, H. Effect of mineral nitrogen fertilizer forms on $\mathrm{N}_{2} \mathrm{O}$ emissions from arable soils in winter wheat production. J. Plant Nutr. Soil Sci. 2014, 177, 722-732. [CrossRef]

23. Skinner, C.; Gattinger, A.; Muller, A.; Mäder, P.; Fließbach, A.; Stolze, M.; Ruser, R.; Niggli, U. Greenhouse gas fluxes from agricultural soils under organic and non-organic management-A global meta-analysis. Sci. Total Environ. 2014, 468-469, 553-563. [CrossRef]

24. Ojima, D.S.; Valentine, D.W.; Mosier, A.R.; Parton, W.J.; Schimel, D.S. Effect of Land-Use Change on Methane Oxidation in Temperate Forest and Grassland Soils. Chemosphere 1993, 26, 675-685. [CrossRef]

25. Dobbie, K.E.; Smith, K.A.; Prieme, A.; Christensen, S.; Degorska, A.; Orlanski, P. Effect of land use on the rate of methane uptake by surface soils in Northern Europe. Atmos. Environ. 1996, 30, 1005-1011. [CrossRef]

26. UBA Daten zur Umwelt. Available online: https:/www.umweltbundesamt.de/publikationen/reaktiverstickstoff-in-deutschland (accessed on 16 March 2020).

27. BMEL. Zukunftstrategie Ökologischer Landbau; Bundesministerium für Ernährung und Landwirtschaft, 2015. Available online: https://www.bmel.de/SharedDocs/Downloads/Broschueren/Zukunftsstrategieoekologischer-Landbau.pdf?__blob=publicationFile (accessed on 16 March 2020).

28. Van Groenigen, J.W.; Velthof, G.L.; Oenema, O.; Van Groenigen, K.J.; Van Kessel, C. Towards an agronomic assessment of $\mathrm{N}_{2} \mathrm{O}$ emissions: A case study for arable crops. Eur. J. Soil Sci. 2010, 61, 903-913. [CrossRef]

29. Petersen, S.O.; Regina, K.; Pöllinger, A.; Rigler, E.; Valli, L.; Yamulki, S.; Esala, M.; Fabbri, C.; Syväsalo, E.; Vinther, F.P. Nitrous oxide emissions from organic and conventional crop rotations in five European countries. Agric. Ecosyst. Environ. 2006, 112, 200-206. [CrossRef]

30. Reinsch, T.; Loges, R.; Kluß, C.; Taube, F. Renovation and conversion of permanent grass-clover swards to pasture or crops: Effects on annual $\mathrm{N}_{2} \mathrm{O}$ emissions in the year after ploughing. Soil Tillage Res. 2018, 175, 119-129. [CrossRef]

31. Brozyna, M.A.; Petersen, S.O.; Chirinda, N.; Olesen, J.E. Effects of grass-clover management and cover crops on nitrogen cycling and nitrous oxide emissions in a stockless organic crop rotation. Agric. Ecosyst. Environ. 2013, 181, 115-126. [CrossRef]

32. Ball, B.C.; Watson, C.A.; Crichton, I. Nitrous oxide emissions, cereal growth, N recovery and soil nitrogen status after ploughing organically managed grass/clover swards. Soil Use Manag. 2007, 23, 145-155. [CrossRef]

33. Bell, M.J.; Hinton, N.J.; Cloy, J.M.; Topp, C.F.E.; Rees, R.M.; Williams, J.R.; Misselbrook, T.H.; Chadwick, D.R. How do emission rates and emission factors for nitrous oxide and ammonia vary with manure type and time of application in a Scottish farmland? Geoderma 2016, 264, 81-93. [CrossRef]

34. Chen, H.; Li, X.; Hu, F.; Shi, W. Soil nitrous oxide emissions following crop residue addition: A meta-analysis. Glob. Chang. Biol. 2013, 19, 2956-2964. [CrossRef]

35. De Ponti, T.; Rijk, B.; van Ittersum, M.K. The crop yield gap between organic and conventional agriculture. Agric. Syst. 2012, 108, 1-9. [CrossRef]

36. Meier, M.S.; Stoessel, F.; Jungbluth, N.; Juraske, R.; Schader, C.; Stolze, M. Environmental impacts of organic and conventional agricultural products-Are the differences captured by life cycle assessment? J. Environ. Manag. 2015, 149, 193-208. [CrossRef]

37. Herrmann, A.; Claus, S.; Loges, R.; Kluß, C.; Taube, F. Can arable forage production be intensified sustainably? A case study from northern Germany. Crop Pasture Sci. 2014, 65, 538-549. [CrossRef]

38. Hansen, S.; Bernard, M.-E.; Rochette, P.; Whalen, J.K.; Dörsch, P. Nitrous oxide emissions from a fertile grassland in Western Norway following the application of inorganic and organic fertilizers. Nutr. Cycl. Agroecosyst. 2014, 98, 71-85. [CrossRef]

39. Kirchmann, H.; Kätterer, T.; Bergström, L.; Börjesson, G.; Bolinder, M.A. Flaws and criteria for design and evaluation of comparative organic and conventional cropping systems. Field Crops Res. 2016, 186, 99-106. [CrossRef] 
40. Høgh-Jensen, H.; Loges, R.; Jørgensen, F.V.; Vinther, F.P.; Jensen, E.S. An empirical model for quantification of symbiotic nitrogen fixation in grass-clover mixtures. Agric. Syst. 2004, 82, 181-194. [CrossRef]

41. Wichmann, S.; Loges, R.; Taube, F. Grain Yield, N2 Fixation and N Balance of Peas, Faba Beans and Narrow-Leafed Lupins in Monocrop and in Intercropping with Cereals. Pflanzenbauwissenschaften 2006, 10, 2-15.

42. Hutchinson, G.L.; Mosier, A.R. Improved Soil Cover Method for Field Measurement of Nitrous-Oxide Fluxes. Soil Sci. Soc. Am. J. 1981, 45, 311-316. [CrossRef]

43. BLE. Getreideeinheitenschlüssel, Bundesanstalt für Landwirtschaft und Ernährung 2012. Available online: https://www.bzl-datenzentrum.de/metanavigation/datendownload/ (accessed on 16 March 2020).

44. Velthof, G.L. Nitrous Oxide Emission from Intensively Managed Grasslands; Wageningen University: Wageningen, The Netherlands, 1997.

45. Clayton, H.; McTaggart, I.P.; Parker, J.; Swan, L.; Smith, K.A. Nitrous oxide emissions from fertilised grassland: A 2-year study of the effects of $\mathrm{N}$ fertiliser form and environmental conditions. Biol. Fertil. Soils 1997, 25, 252-260. [CrossRef]

46. Dittert, K.; Lampe, C.; Gasche, R.; Butterbach-Bahl, K.; Wachendorf, M.; Papen, H.; Sattelmacher, B.; Taube, F. Short-term effects of single or combined application of mineral $\mathrm{N}$ fertilizer and cattle slurry on the fluxes of radiatively active trace gases from grassland soil. Soil Biol. Biochem. 2005, 37, 1665-1674. [CrossRef]

47. Velthof, G.L.; Kuikman, P.J.; Oenema, O. Nitrous oxide emission from animal manures applied to soil under controlled conditions. Biol. Fertil. Soils 2003, 37, 221-230. [CrossRef]

48. Bell, M.J.; Hinton, N.; Cloy, J.M.; Topp, C.F.E.; Rees, R.M.; Cardenas, L.; Scott, T.; Webster, C.; Ashton, R.W.; Whitmore, A.P.; et al. Nitrous oxide emissions from fertilised UK arable soils: Fluxes, emission factors and mitigation. Agric. Ecosyst. Environ. 2015, 212, 134-147. [CrossRef]

49. Jones, S.K.; Rees, R.M.; Skiba, U.M.; Ball, B.C. Influence of organic and mineral $\mathrm{N}$ fertiliser on $\mathrm{N}_{2} \mathrm{O}$ fluxes from a temperate grassland. Agric. Ecosyst. Environ. 2007, 121, 74-83. [CrossRef]

50. Henriksen, T.M.; Breland, T.A. Evaluation of criteria for describing crop residue degradability in a model of carbon and nitrogen turnover in soil. Soil Biol. Biochem. 1999, 31, 1135-1149. [CrossRef]

51. Loges, R.; Bunne, I.; Reinsch, T.; Malisch, C.; Kluß, C.; Herrmann, A.; Taube, F. Forage production in rotational systems generates similar yields compared to maize monocultures but improves soil carbon stocks. Eur. J. Agron. 2018, 97, 11-19. [CrossRef]

52. Benoit, M.; Garnier, J.; Anglade, J.; Billen, G. Nitrate leaching from organic and conventional arable crop farms in the Seine Basin (France). Nutr. Cycl. Agroecosyst. 2014, 100, 285-299. [CrossRef]

53. Schmeer, M.; Loges, R.; Dittert, K.; Senbayram, M.; Horn, R.; Taube, F. Legume-based forage production systems reduce nitrous oxide emissions. Soil Tillage Res. 2014, 143, 17-25. [CrossRef]

54. Wuebbles, D.J.; Hayhoe, K. Atmospheric methane and global change. Earth Sci. Rev. 2002, 57, 177-210. [CrossRef]

55. Boeckx, P.; Van Cleemput, O. Estimates of $\mathrm{N}_{2} \mathrm{O}$ and $\mathrm{CH}_{4}$ fluxes from agricultural lands in various regions in Europe. Nutr. Cycl. Agroecosyst. 2001, 60, 35-47. [CrossRef]

56. Kirschke, S.; Bousquet, P.; Ciais, P.; Saunois, M.; Canadell, J.G.; Dlugokencky, E.J.; Bergamaschi, P.; Bergmann, D.; Blake, D.R.; Bruhwiler, L.; et al. Three decades of global methane sources and sinks. Nat. Geosci. 2013, 6, 813. [CrossRef]

57. Hütsch, B.W.; Webster, C.P.; Powlson, D.S. Long-term effects of nitrogen fertilization on methane oxidation in soil of the broadbalk wheat experiment. Soil Biol. Biochem. 1993, 25, 1307-1315. [CrossRef]

58. Willison, T.W.; Webster, C.P.; Goulding, K.W.T.; Powlson, D.S. Methane oxidation in temperate soils: Effects of land use and the chemical form of nitrogen fertilizer. Chemosphere 1995, 30, 539-546. [CrossRef]

59. Boeckx, P.; Van Cleemput, O.; Villaralvo, I. Methane oxidation in soils with different textures and land use. Nutr. Cycl. Agroecosyst. 1997, 49, 91-95. [CrossRef]

60. Seufert, V.; Ramankutty, N.; Foley, J.A. Comparing the yields of organic and conventional agriculture. Nature 2012, 485, 229. [CrossRef]

61. Cederberg, C.; Mattsson, B. Life cycle assessment of milk production-A comparison of conventional and organic farming. J. Clean. Prod. 2000, 8, 49-60. [CrossRef]

62. Korsaeth, A. Relations between nitrogen leaching and food productivity in organic and conventional cropping systems in a long-term field study. Agric. Ecosyst. Environ. 2008, 127, 177-188. [CrossRef] 
63. Flessa, H.; Ruser, R.; Dörsch, P.; Kamp, T.; Jimenez, M.A.; Munch, J.C.; Beese, F. Integrated evaluation of greenhouse gas emissions (CO2, $\mathrm{CH} 4, \mathrm{~N} 2 \mathrm{O})$ from two farming systems in southern Germany. Agric. Ecosyst. Environ. 2002, 91, 175-189. [CrossRef]

64. Chirindaa, N.; Carter, S.; Albert, K.R.; Ambus, P.; Olesen, J.E.; Porter, J.R.; Petersen, S.O. Emissions of nitrous oxide from arable organic and conventional cropping systems on two soil types. Agric. Ecosyst. Environ. 2010, 136, 199-208. [CrossRef]

65. Knudsen, M.T.; Meyer-Aurich, A.; Olesen, J.E.; Chirinda, N.; Hermansen, J.E. Carbon footprints of crops from organic and conventional arable crop rotations-Using a life cycle assessment approach. J. Clean. Prod. 2014, 64, 609-618. [CrossRef]

66. Irmler, U. Changes in earthworm populations during conversion from conventional to organic farming. Agric. Ecosyst. Environ. 2010, 135, 194-198. [CrossRef]

67. Schröter, L.; Irmler, U. Organic cultivation reduces barrier effect of arable fields on species diversity. Agric. Ecosyst. Environ. 2013, 164, 176-180. [CrossRef]

68. Möller, K.; Stinner, W.; Leithold, G. Growth, composition, biological N 2 fixation and nutrient uptake of a leguminous cover crop mixture and the effect of their removal on field nitrogen balances and nitrate leaching risk. Nutr. Cycl. Agroecosyst. 2008, 82, 233-249. [CrossRef]

69. Nemecek, T.; Dubois, D.; Huguenin-Elie, O.; Gaillard, G. Life cycle assessment of Swiss farming systems: I. Integrated and organic farming. Agric. Syst. 2011, 104, 217-232. [CrossRef]

70. Tuomisto, H.L.; Hodge, I.D.; Riordan, P.; Macdonald, D.W. Does organic farming reduce environmental impacts?-A meta-analysis of European research. J. Environ. Manag. 2012, 112, 309-320. [CrossRef]

(C) 2020 by the authors. Licensee MDPI, Basel, Switzerland. This article is an open access article distributed under the terms and conditions of the Creative Commons Attribution (CC BY) license (http://creativecommons.org/licenses/by/4.0/). 